Aletria, Belo Horizonte, v. 31, n. 3, p. 145-165, 2021

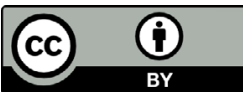

\title{
Os verdes mares bravios do Turista aprendiz ${ }^{1}$
}

\section{The Green Wild Seas of Turista aprendiz}

\author{
Rodrigo de Albuquerque Marques \\ Universidade Estadual do Ceará (UECE), Fortaleza, Ceará / Brasil \\ rodrigo.marques@uece.br \\ https://orcid.org/0000-0002-9571-8554
}

Resumo: O presente artigo descreve um trecho da viagem de Mário de Andrade ao Norte e Nordeste do país em 1927. Refere-se às passagens e iconografias de O Turista aprendiz: (Viagens pelo Amazonas até o Peru, pelo Madeira até a Bolivia e por Marajó até dizer chega), diário de viagem do modernista, nas quais o estado do Ceará e a sua capital Fortaleza aparecem não só como espaço geográfico, mas como espaço simbólico e literário. $\mathrm{O}$ artigo reflete como um dia de passeio de Mário de Andrade na capital cearense, levou-o a refletir sobre a poesia de Castro Alves e a prosa de José de Alencar, revisando, no curso do diário, concepções românticas acerca da relação entre as forças de nossa natureza tropical e uma literatura nacional autêntica.

Palavras-chave: Mário de Andrade; O Turista aprendiz; Ceará; Modernismo; Romantismo.

Abstract: This article describes a passage from Mário de Andrade's trip to the North and Northeast of the country in 1927. It refers to the passages and iconographies of O turistaaprendiz: (Viagenspelo Amazonas até o Peru, pelo Madeira até a Bolívia e porMarajó até dizer chega), travel diary, in which the state of Ceará and its capital Fortaleza appear not only as ageographical space, but as a symbolic and literary space. The article reflects how Mário de Andrade's day in the capital of Ceará led him to reflect on Castro Alves' poetry and José de Alencar's prose, reviewing, in the course of the diary, the romantic conceptions about the relationship between strengths of our tropical Nature and authentic national literature.

Keywords: Mário de Andrade; O Turista aprendiz; Ceará; Modernism; Romantism.

${ }^{1}$ Este artigo é resultado da pesquisa "A participação de Mário de Andrade no Ceará: Modernismo, viagens e leituras", do Programa de Pós-Doutorado da Faculdade de Filosofia, Letras e Ciências Humanas (FFLCH-USP), sob a supervisão da Profa. Dra. Iumna Maria Simon. 
O correio chegou e na minha correspondência estava um jornal, quem me mandou não sei. Era um diário de uma linda capital do Norte. Já estive nela, passei lá um dia sublime, até colhi conchinhas na praia.

Mário de Andrade. Os filhos da Candinha.

No Ceará da segunda metade dos anos 1920, o nome de Mário de Andrade figurava às vezes vinculado ao homônimo Mário Sobreira de Andrade, ou melhor, ao Mário de Andrade (do Norte), com brincadeiras e gozações, e nada mais. Bem diferente se comparado a Pernambuco ou ao Rio Grande do Norte, onde o paulista nutria, desde antes, amizade com Joaquim Inojosa, Cícero Dias, Ascenso Ferreira, Jorge Fernandes, Luís da Câmara Cascudo e Antônio Bento de Araújo Lima, e o seu nome aparecia em periódicos daquelas províncias como principal referência da nova corrente literária surgida em São Paulo.

No entanto, em 1939, Mário iniciaria uma correspondência com jovens poetas e romancistas cearenses ávidos por conselhos, contatos e leituras ${ }^{2}$. Mas no ano da viagem, em 1927, ninguém o aguardava quando, do navio Pedro I, desembarcou na terra de Alencar ao lado de Dona Olívia Guedes Penteado ("A Rainha" ou "a Rainha do Café"), Margarida Guedes Penteado ("Mag" ou "Balança") e Dulce do Amaral Pinto ("Dolur", a "Trombeta"), filha do primeiro casamento de Tarsila do Amaral. O grupo atracou na Praia de Iracema a bordo de uma jangada de piúba ou talvez de uma pequena canoa tripulada por algum experiente jangadeiro, pois assim se fazia à época, enquanto o navio-grande dormia ancorado num ponto mais distante da costa. A chegada da trupe paulista não foi muito diferente do desembarque de Joaquim de Almeida Leite Moraes, avô materno de Mário, em 1882, a bordo do vapor Ceará no mesmo local:

"E às três horas da tarde o Ceará fundeia-se em frente de Fortaleza; maré cheia; desembarque perigosíssimo nas jangadas; os passageiros preferem ficar a bordo; eu só quebro a unanimidade e delibero desembarcar-me" (MORAES, 1990, grifo do autor).

A coisa só ia mudar mesmo a partir de 1950 com a inauguração do porto da enseada do Mucuripe.

2 A segunda geração modernista do Ceará deferiu grau de mestre ao poeta e o destinatário não se fez de rogado, respondia atenciosamente aos autores do Grupo Clã do Ceará, principalmente a Antônio Girão Barroso, Aluízio Medeiros e Eduardo Campos. 
A primeira fotografia que Mário tirou no Ceará vem descrita exatamente assim: "canoas encostadas no navio"; e a outra, em seguida: "jangadas vistas do alto"; se juntarmos as duas fotografias a uma das passagens do diário, não a do dia das fotos, 05 de agosto, quando desembarcou, mas a do dia 17 de maio, quando apenas permanecera em cabotagem, teremos uma descrição rica da proximidade do litoral cearense:

17 de maio. Não descemos que a parada era mínima. Rendeiras a bordo - essas fatalidades que a gente já sabe que vai encontrar na cidade Fulana... Imagina a gente encontrar rendeiras cearenses no Havre, que maravilha! E choferes franceses, bem maleducados em Botucatu... Vida de bordo. (ANDRADE, 2015, p. 65) . $^{3}$

A renda cearense, urdida em uma espécie de almofada espetada por alfinetes ou por espinhos de mandacaru, dispostos segundo o desenho de um molde ("papelões"), posta entre as pernas de uma artesã que com destreza traça as linhas de um labirinto, é um artesanato típico da região, constituindo parte do imaginário e da identidade do estado, principalmente da zona costeira ${ }^{4}$. A julgar pelas palavras do turista Mário,

${ }^{3}$ Graça Aranha, em suas memórias, menciona também um comércio ambulante sobre as águas cearenses: "Os jangadeiros solicitavam passageiros para terra, vendiam pássaros, graúnas, corrupiões, macacos, sauins, vendiam cocos, rapaduras, bolos de milho, tudo ostentando uma fartura incrível na terra da seca e da desolação" (ARANHA, 1931, p. 138). Mário não descreve tal natureza de víveres, refere-se apenas à oferta de rendas pelas próprias rendeiras.

${ }_{4}^{4}$ A renda no Brasil não se fixou apenas no Nordeste, a sua produção também aparece mais ao Sul do Brasil e em outras regiões da América Latina, como demonstrou a exposição História das mulheres, histórias feministas, ocorrida de agosto e novembro de 2019 no Museu de Arte de São Paulo (MASP): "Diferentemente do bordado, feito sobre um tecido já existente, o processo de confecção da renda envolve a criação de imagens que constroem também a materialidade do tecido: os fios se sustentam e se unem, entrelaçados como 'pontos no ar'. As rendas foram difundidas e aprimoradas na Europa a partir do século 16, mas já eram conhecidas por chineses, indianos, persas, turcos e japoneses. É comum que se assuma que, no Brasil, a técnica tenha sido trazida pelos colonizadores portugueses, mas essa é apenas uma parte da história. A cultura Chancay, que ocupou o território do atual Peru entre 1100 e 1430, aproximadamente, produziu rendas sofisticadas, como atestam os exemplares do comodato MASP Landmann" (legenda da Exposição de nove rendas que integram a coleção de Ellen WeegeVollmer (1929-2017), preservadas na coleção de Museu de Hábitos e Costumes, em Blumenau. 
em 1927, a renda integrava o conjunto simbólico dos cearenses, pois já se esperava encontrá-la à venda ainda em alto mar5 .

Em pedido a Câmara Cascudo, quando em 1928 revisava a escrita de Macunaíma, Mário de Andrade solicitou nomes de rendeiras para ilustrar melhor uma passagem do livro. Cascudo atendeu ao amigo e entregou-lhe nomes como "Bertholina", moradora em Tibau, praia de Mossoró, Dona Geracina, de Ponta do Mangue, em Natal, e outras, além de informações detalhadas sobre a diversidade das rendas, essas mulheres figuraram em Macunaíma :

[...]. As rendeiras da praia são as melhores e guardam, como herança, os "papelões" com desenhos de velhas rendas, passadas de pais e filhos. Estes cartões têm nomes e estes denominam as rendas. Ex: Meu coração é teu, Rosa dos Alpes, Por ti padeço, Ninho de abelha, Singeleza, Renda de Sol, Flor de guabiraba. Às vezes o número dos pares de bilros batiza a renda. Assim, Cinco Pares, Seis Pares, a célebre Oito Pares, etc. A rendeira tem um ciúme feroz dos seus "papelões". A belíssima Ninho de Abelha foi muito tempo monopólio das rendeiras de Muriú. Assim Renda Sol em Touros. Outra coisa. Os bilros servem de jornal amoroso. V. encontra raramente um bilro sem inscrição e desenho recordador entalhado a canivete. Datas, letras, riscos, monogramas lembram fatos e homens. (CASCUDO; ANDRADE, 2010, p.145)

$\mathrm{O}$ interesse pelas rendas expresso na carta a Cascudo destoa um pouco do tédio com que o turista recebeu as rendeiras a bordo, pois Mário, no diário, faz uma brincadeira invertendo o pitoresco do Brasil com a modernidade francesa: "rendeiras cearenses no Havre e choferes franceses maleducados em Botucatu". Caso de fato a troca ocorresse, para o viajante, seria uma grata surpresa pela simples quebra de expectativa de quem viaja a passeio. Por outro lado, a piada

\footnotetext{
5 "As mulheres e filhas dos pescadores auxiliavam os maridos em atividades em casa ou nos arredores, seja fazendo rendas, lavando roupa para fora,costurando a roupa da família ou cuidando da farta prole que nascia a cada ano, fazendo enfim, 'ajudamento de mulher', como disse Jacaré ao repórter do jornal A Manhã, do Rio de Janeiro" (ABREU, 2012, p. 61).

6 "Mandaram buscar pra ele em São Paulo os famosos sapatinhos de lã tricotados por dona Ana Francisca de Almeida Leite Morais e em Pernambuco as rendas "Rosa dos Alpes", "Flor de Guabiroba" e "Por ti padeço" tecidas pelas mãos de dona Joaquina Leitão mais conhecida pelo nome de Quinquina Cacunda” (ANDRADE, 2001, p. 28).
} 
sintoniza-se perfeitamente com as ideias nacionalistas que Mário vinha construindo. A hipotética presença da renda cearense na Normandia não deixava de ser uma metáfora da internacionalização da cultura brasileira, invertendo a visão eurocêntrica que tanto Mário quanto Oswald questionavam. A troca era injusta, pois, na outra ponta, enquanto o Havre ficaria com as maravilhosas rendas cearenses, Botucatu, cidade do interior paulista, receberia choferes franceses "maleducados".

Ora, o elaborado trabalho das nordestinas encontra-se num patamar superior de técnica, beleza e tradição, como vimos descrito na carta de Câmara Cascudo, se comparado ao trabalho mecânico de um chofer de carro, mas, mesmo assim, o saldo negativo pesaria para o país menos industrializado que amargaria, como resultado da permuta, a "maleducação" dos motoristas estrangeiros. Em termos amplos, a piada reforça o entendimento de que o Modernismo reinterpretou como superioridade nossas deficiências supostas ou reais, no caso, supostas, a das rendeiras, e reivindicou para si um nacionalismo de base crítica (cf. CANDIDO, 2010, p. 126).

O episódio das tecelãs, cabe relembrar, ocorreu a 18 de maio de 1927 quando o grupo paulista estava em cabotagem para seguir dali à foz do rio Amazonas. Ele e elas só desceriam à Praia de Iracema na volta. As anotações dos dias 16, 17 e 18 de maio de 1927 descrevem apenas impressões do mar, mas vêm recheadas de saborosas citações como esta da rendeira.

No dia 16, por exemplo, quando se aproximava o mar esverdeado do Ceará, Mário escreveu:

"Dobra-se o cabo Roque. Mar do Ceará. Amanhã chegaremos a Fortaleza. Decerto é a lembrança da Padaria espiritual que me vende um biscoito de Horácio. 'Gosto das vênus fáceis e prontinhas' eu mastigava ao luar. Engoli em seco" (ANDRADE, 2015, p. 64).

A “Padaria Espiritual” mencionada não é alguma seita esotérica, refere-se ao grupo literário mais famoso que o Ceará produziu. Por uma série de circunstâncias, o Ceará, surpreendentemente, foi um estado brasileiro que, mesmo longe do centro hegemônico do país, desenvolveu bastante o seu ambiente literário na segunda metade do século XIX. O cume desse processo se deu em 1892, com o surgimento da Padaria Espiritual, um movimento de "proletários intelectuais" que colocou o cenário cultural de Fortaleza na berlinda nacional. A Padaria iniciou não só uma prática historiográfica das letras cearenses, a partir de um 
escrito do seu fundador, o poeta Antônio Sales, como consolidou uma "tradição literária" no estado (cf. MARQUES, 2018b, p. 20). Não era a primeira vez que Mário demonstrava sua simpatia pelo movimento dos padeiros, cujo bom humor por vezes é comparado ao humour antiburguês da Semana de Arte Moderna de 1922, em Paulicéia desvairada, livro de 1921, ele já aludira à agremiação cearense no poema "Rua de São Bento" (ANDRADE, 2002, p. 54):
Clube Comercial... A Padaria Espiritual...
Mas a desilusão dos sombrais amorosos
põe majorationtemporaire, $100 \% \mathrm{nt} ! \ldots$
Minha loucura, acalma-te!
Veste o water-proof dos tambéns! $!^{7}$

No convés, o mar e a lembrança dos padeiros do Ceará lhe inspiraram o verso: "Gosto das vênus fáceis e prontinhas", que Mário compara a um biscoito de Horácio servido ainda quente, verso que, pelo seu caráter sensual e pela solidão da vida a bordo, teve de mastigá-lo a seco e ao luar. No dia seguinte, deu-se o episódio das rendeiras já comentado. Neste ponto do diário, é visível a ansiedade para encontrar o mais breve possível a foz do rio Amazonas, motivo da expedição turística. A vontade de deixar para trás as praias nordestinas e seguir ao encontro do grande rio com o mar é expressa na entrada do dia 18. A hesitação ou excitação deste trecho da viagem perturbou, ao que parece, a pena do escritor que repetiu indevidamente a mesma data no diário:

\footnotetext{
7 Antônio Sales estava no Rio de Janeiro em 1923 e por certo leu os versos de Mário, pois, apesar da pouca tiragem de Paulicéia desvairada, Sales, um dos jornalistas e escritores mais bem reputados da capital fluminense, mantinha-se sempre a par das novidades literárias. Tanto que neste mesmo ano, ao regressar a Fortaleza, estreou no Correio do Ceará uma série de paródias contra o Futurismo sob o pseudônimo de Arthunio Vales. Eram as "Estâncias futuristas" que causaram certo frisson na capital alencarina e acabaram por trazer a crítica antes mesmo que o Modernismo chegasse propriamente, vacinando a cena literária local contra a novidade "sem pé nem cabeça" que soprava do Sul. A última das "Estâncias futuristas", a de número XVIII, parodiava o poema "A caçada" de Mário de Andrade, desconstruindo-o a partir do cotidiano da Praça do Ferreira, à época centro nervoso de Fortaleza (ver MARQUES, 2018a). E assim filtradas pela sátira do padeiromor Moacir Jurema, as ideias e a poesia de Mário de Andrade repercutiriam no Ceará pela primeira vez. Se a geração parnasiana no Ceará era sinceramente avessa às modernices do Sul, fato que não destoava do meio literário de outras regiões do país, por outro lado, a simpatia de Mário pela Padaria espiritual também era sincera.
} 
18 de maio. A bordo. Amanhecemos em pleno canavial. A isso chamam por aqui de "verdes mares bravios"... É um canavial e não tem nada de bravo. Pelo contrário é meigo,serviçal como um Chalaça e o Pedro I amonta nele e faz o que bem entende. Até dá raiva. Banza banza namora come cana enquanto a gente está impaciente pra ver a foz do Amazonas amanhã. Foz do Amazonas... (ANDRADE, 2015, p. 66)

No Ceará, é comum o visitante ou o nativo, ao encostar-se numa balaustrada de beira de praia, repetir ao léu o início de Iracema: "Verdes mares bravios de minha terra natal", tamanha a união da obra de José de Alencar com a paisagem. Mas para o modernista a passeio aquele mar verde não lhe pareceu bravio, pelo contrário, mostrou-se-lhe mais aparentado a um canavial manso e aborrecido. O navio Pedro I se transformou, na prosa do paulista, num ruminante lento e preguiçoso, saboreando aquele pasto sem fim, indiferente ao desejo dos nautas de dar de frente com a foz amazônica o quanto antes. $\mathrm{O}$ mar também é comparado a Chalaça, "brincadeira ligando o nome da embarcação ao cognome Chalaça, de Francisco Gomes da Silva (Lisboa, 1791 - 1852), amigo e assessor de Pedro I, Imperador do Brasil" (ANDRADE, 2015, p. 66). Ao metamorfosear os "verdes mares bravios" num imenso canavial, Mário de Andrade inverte o campo semântico original: se o mar alencarino é animal indócil, o que nos conduz a outros adjetivos como "primitivo", "selvagem", "bárbaro"; o mar do modernista é vegetal, caudalosamente manso, um pasto, civilizado por demais.

A diferença desses olhares diz muito das concepções nacionalistas que Alencar e Mário desenvolveram. Na primeira carta que abre a polêmica sobre a Confederação dos Tamoios, José de Alencar, ao retoricamente divagar caso fosse poeta, afirma que esqueceria a civilização para aprofundar-se na natureza sem com isto ostentar qualquer forma de preconceito:

Digo-o por mim: se algum dia fosse poeta, e quisesse cantar a minha terra e as suas bellezas, se quisesse compor um poema nacional, pediria a Deus que me fizesse esquecer por um momento as minhas idéas de homem civilisado. (ALENCAR, 1856, p. 6)

E se Deus assim o permitisse, o passo seguinte seria embrenharse na mata nativa, desvendar as regiões mais longínquas da pátria para senti-la ainda virgem: 
Filho da natureza por essas mattas seculares; contemplaria as maravilhas de Deus, veria o sól erguer-se no seu mar de ouro, a lua deslisar-se no azul do céo; ouviria o murmurio das ondas e o écho profundo e solemne das florestas. (ALENCAR, 1856, p. 6-7)

De tal espírito romântico, só poderia mesmo resultar uma invocação forte e grandiloquente como "os verdes mares bravios", adequada à abertura das pretensões de Iracema. Natureza e civilização estariam em pólos distintos e antagônicos, com a desvantagem para a primeira, uma vez que o avanço civilizatório seria inexorável:

E entretanto a civilização ahi vem; o wagon do progresso fumega e vai precipitar-se sobre essa têaimmensa de trilhos de ferro que em pouco cortarão as tuas florestas virgens; os turbilhões de fumaça e de vapor começão a ennovelar-se, e breve obscurecerão a limpidez d'essa atmospheradiaphana e pura. (ALENCAR, 1856, p. 7)

Concepção distinta está na visão de Mário, que vê o mar cearense como um extenso canavial.

Apesar de a natureza evocar o sublime, há uma espécie de dolência que contamina o arredor e a própria embarcação através dos adjetivos, "meigo", "serviçal", "chalaça", pois até o navio "Pedro I" se transmuta macunaimicamente: banza, banza, namora e chupa cana ${ }^{8}$. Longe de estar apartada da civilização, a natureza se amalgama com a cultura do país e com o caráter de o seu povo. Trata-se de um daqueles momentos do Turista aprendiz quando o autor devaneia e pinta quadros de inspiração surrealista, acrescentando ao registro da excussão uma camada ficcional. Essa emerge da cultura brasileira, não só pelo canavial, primeiro ciclo econômico da colonização, mas pelo repertório do cancioneiro popular que tematiza a maré caprichosa que retarda as embarcações, brincando com a sorte dos marinheiros, como na Nau Catarineta ou nos versos iniciais de "Peixe Vivo":

${ }^{8}$ O substantivo próprio "Chalaça" tem clara função acessória no texto, ainda se pensarmos que o famoso assessor de Pedro I, no texto de Mário, continua com seu encargo de alcoviteiro, pois facilita ao navio seu namoro com o mar. 


\author{
Zunzum, lá no meio do mar \\ é a onda que nos atrasa \\ é o mar que nos atrapalha \\ para no porto chegar.
}

(GRAVAÇÃO...,2015) ${ }^{9}$

Os verdes mares cearenses de $O$ Turista aprendiz vêm temperados assim pelo sal da tradição popular, no mesmo molde da rapsódia do herói Macunaíma, na qual as lendas, os mitos, as cantigas, os provérbios, a música e as danças comparecem fundidos com a paisagem, a linguagem e a geografia nacional. Não que esta fusão seja pacífica ou harmoniosa, é uma forma de convívio que tensiona a oposição "natureza brasileira"/ "civilização europeia"10. O resultado desse embate traz perdas e ganhos para ambos, pois embora a natureza se coloque como Chalaça, a serviço do Imperador, em contradança, retarda, com cuidados, o avanço desenfreado da civilização, seduzindo maliciosamente para um tempo contemplativo as conquistas técnicas do processo civilizacional.

O "Amanhecemos em pleno canavial" não só evoca José de Alencar como remete a um verso igualmente famoso de outro romântico: Castro Alves e a abertura poderosa, in media res, de o "Navio Negreiro": "S'tamos em pleno mar". "Amanhecemos em pleno Canavial" parece responder ao impulso do que representavam aquelas paisagens, segundo ainda o autor, adjetivadas com a grandiosidade do poeta baiano:

Não sei, quero resumir minhas impressões desta viagem litorânea por Nordeste e Norte do Brasil, não consigo bem, estou um pouco

\footnotetext{
9 Cantados por Mário de Andrade e Mary (Houston) Pedrosa em gravação descoberta na biblioteca de Washington.

${ }^{10}$ Gilda de Mello e Souza em $O$ tupi e o alaúde sobre Macunaíma reflete aspecto semelhante: "Macunaíma representa, pois, uma meditação extremamente complexa sobre o Brasil, efetuada através de um discurso selvagem, rico de metáforas, símbolos e alegorias. Os recursos de composição acentuam em vários níveis - no tratamento do espaço e do tempo (ambientação do cenário); na caracterização física, psicológica e cultural das personagens: na distribuição por simetria inversa dos dois grandes movimentos sintagmáticos básicos; no jogo de oposição de dois dísticos; na significação do episódio principal - uma tensão não resolvida, uma contradição que é erigida em traço expressivo do entrecho. De certo modo o livro é - como define o seu autor - "a aceitação sem timidez nem vanglória da entidade nacional", concebida por este motivo "permanente e unida", na desgeografização intencional do clima, da flora, da fauna, do homem, da lenda e da tradição histórica. A lucidez da análise satiriza um estado de coisas mas não aponta uma solução. No final de um dos prefácios, Mário de Andrade sublinha o aspecto sem compromisso do livro, que a seu ver é característico das épocas de transição social, que não desejam a volta do passado, não sabem o que tem de vir e sentem o presente "como uma neblina vasta"; aspecto - conclui - que nos impede de “tirar dele uma fábula normativa”. (SOUZA, 1979, p. 96-97).
} 
aturdido, maravilhado, mas não sei... Há uma espécie de sensação ficada da insuficiência, de sarapintação, que me estraga todo o europeu cinzento e bem arranjadinho que ainda tenho dentro de mim. Por enquanto, o que mais me parece é que tanto a natureza como a vida destes lugares foram feitos muito às pressas, com excesso de castro-alves. (ANDRADE, 2015, p. 67)

A paisagem do litoral nordestino atordoou, ao que parece, não só aspectos psicológicos de Mário de Andrade, mas os conceitos modernos enraizados na sua formação intelectual, tais como as ideias de estado, povo, nação e cultura. Neste período, Mário de Andrade andava às voltas com uma nova concepção de nacionalismo que passava pela reelaboração de sua episteme de homem erudito, versado na música, na literatura e nas línguas germânicas, francesas, portuguesas etc. A rusticidade da natureza nordestina, feita assim "muito às pressas", desafiava-o intelectualmente para deslocar opções artísticas "arranjadinhas", "cinzentas", à europeia, e confrontá-las com uma realidade que um só Castro Alves, apesar de toda a exuberância rítmica e imagética de sua poesia, não dava cabo. Aqui não se trata de um gênio criador que pinta a natureza do seu país, mas a própria natureza que se encharca com extravagância do legado de um poeta seu $^{11}$. Essa visão atordoadora do litoral nordestino toca no inconsciente da nossa condição colonial e das nossas tentativas de autocompreensão que, pela primeira vez, com o Modernismo, punham em xeque não mais a nossa "herança selvagem", mas o outro pólo: a cultura da metrópole. A consequência do embate seria a projeção de uma utopia nacional que tocasse fundo na sua matéria que, em potência, poderia nos singularizar com mais força e honestidade:

E esta pré-noção invencível, mas invencível, de que o Brasil em vez de se utilizar da África e da Índia que teve em si, desperdiçouas, enfeitando com elas apenas a sua fisionomia, suas epidermes, sambas, maracatus, trajes, cores, vocabulários, quitutes... E deixou-se ficar, por dentro, justamente naquilo que, pelo clima, pela raça, alimentação, tudo, não poderá nunca ser, mas apenas macaquear, a Europa. Nos orgulhamos de ser o único grande (grande?) país civilizado tropical... Isso é o nosso defeito, a nossa impotência. Devíamos pensar, sentir como indianos, chins, gente

\footnotetext{
${ }^{11}$ No estudo que fez sobre Castro Alves, ao compará-lo a Fagundes Varela, Mário de Andrade ressalta a plasticidade dos versos do baiano ao retratar a paisagem brasileira: " $\mathrm{Da}$ sonoridade precisava ele, e a empregou com excelência muitas vezes. Mas, em vez de música, a palavra virou luz, ou melhor, escultura. De subjetiva ela passou a objetiva. Foi uma restrição imensa, um apoucamento formidável, a palavra assim tomada como uma particular. Pegue-se uma descrição de Castro Alvez e outra de Varela, a diferença é sensível. Castro Alves é infinitamente mais local, mais saboroso, mais exato. A gente vê a paisagem e sente o momento, o gosto da fruta, a umidade do rio". (ANDRADE, 2002, p. 139)
} 
do Benin, de Java... Talvez então pudéssemos criar cultura e civilização próprias. Pelo menos seríamos mais nós, tenho certeza. (ANDRADE, 2015, p. 67-68)

O emergir desta "civilização tropical" seria uma superação de dentro para fora do nosso colonialismo, e a própria natureza poderia, por fim, se colorir para além dos excessos de Castro Alves, libertando-nos do pensamento burguês europeizado ou, em outras palavras, daquilo que, segundo Mário de Andrade, fazia tão atraente a poesia de Castro Alves: "Atrai porque é mais fácil; e a preguiça tendenciosa de todos nós, a lei do menor esforço, nos leva a nos ilharmos burguesamente na... terra curta do pensamento lógico" (ANDRADE, 2002,p. 139). Essas reflexões de O Turista aprendiz, e o próprio livro no geral, busca registrar uma viagem de descoberta interior (interior no sentido de autoconhecimento) do Brasil que passava irremediavelmente por um descentramento epistêmico.

O litoral nordestino, como as outras regiões periféricas do país, ia-se, desta maneira, modernizando-se com o toque de Mário tendo como pontos de partida as potencialidades naturais e a releitura do cânone literário. Em contrapartida, Mário e os paulistas iam-se abrasileirando, como se a sentença dos frades franciscanos que encontrariam em Tonantins, Amazonas, estivesse sendo executada na carne dos viajantes: "- Vocês são paulistas... Vocês não são brasileiros não! Pra ser brasileiro precisa vir no Amazonas, aqui sim! Você (apontou pra mim) tem pronúncia própria de italiano" (ANDRADE, 2015, p. 113).

Sem o Brasil por inteiro, as ideias da Semana de 1922 perderiam sentido, uma vez que a desigualdade e a diversidade regional integravam os princípios estéticos, as políticas de divulgação, as utopias, a execução do movimento e a sua inserção no cenário internacional.

Mas está na hora de deixarmos os verdes mares bravios ou os canaviais em pleno mar para seguir o itinerário a bordo do Pedro I com a turma de Dona Maria Guedes Penteado. O que nos interessa, entretanto, é a volta da viagem. Depois da experiência amazônica, o grupo volta a São Paulo, e, no trajeto, uma das capitais que param para conhecer é justamente Fortaleza.

O dia 05 de agosto de 1927 vem duplicado no diário de Mário de Andrade: no primeiro registro, traça um perfil do poeta neoclássico José de Abreu Albano, nascido no Ceará em 1882: "Era alto, pálido, usava barba; duma maravilhosa beleza física. Sempre com uma enorme faca no colete e que jogava como ninguém" (ANDRADE, 2015, p. 196); no segundo registro, narra o passeio pelas ruas de Fortaleza e pela praia de Iracema.

A parte dedicada ao poeta Albano é bem maior do que a dedicada ao tour pela cidade, e constitui uma fonte para quem estuda o camoniano que tanto Manuel Bandeira admirou ${ }^{12}$. Conhecido pela excentricidade e

${ }^{12}$ ALBANO, José. Rimas. Rio de Janeiro:Pongetti, 1948. 
megalomania, José Albano acumulou perfis anedóticos sobre sua vida de dândi poliglota e peregrino. O cearense falava latim, inglês, espanhol, grego e árabe. Boa parte da vida passou em aventuras pela Europa, África e Ásia, sozinho ou com a família, palmilhando territórios arrasados por guerras, até encontrar o fim da vida na França. Esta figura trágica e exótica da literatura brasileira aparece n'O Turista aprendiz através das anedotas contadas por Paulo Prado e o filho:

Dizia que na Espanha fizera uma conferência e os críticos garantiram que, depois de Cervantes, ninguém escrevera tão lindo e perfeito espanhol. Dizia na sua loucura que não pudera viver em França porque a Academia Francesa, vendo que ele escrevia melhor que todos e dispunha melhor que todos dos segredos do bem-escrever, o tinha indisposto com Clemenceau e este o expulsara do seu convívio e da França. (ANDRADE, 2015, p. 196).

Mais uma vez, a proximidade das terras de Bárbara de Alencar fez Mário acender seu interesse pela literatura: na ida, a Padaria espiritual e José de Alencar; na volta, José Albano.

Por fim, Mário de Andrade desembarca. Sorridente, bem composto, com o terno de linho branco que mandara coser em Belém, recostou-se na amurada do cais de Fortaleza para uma foto (Figura 1), que se encontra no Acervo do Instituto de Estudos Brasileiros (IEB) sob a legenda "No pontão de Fortaleza".

Figura 1 - Mário no pontão de Fortaleza

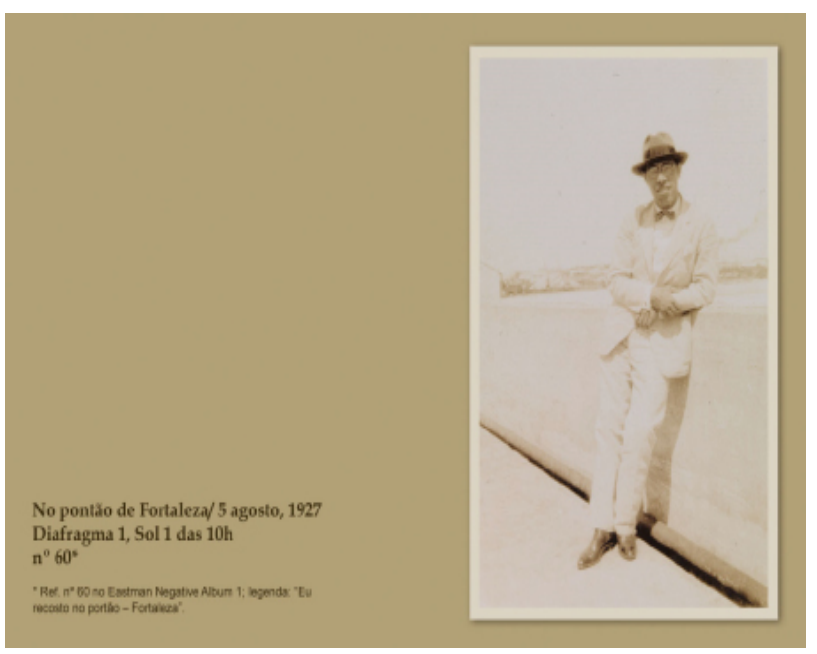

Fonte: Andrade (1927a). 
Diferente do que ocorrera em quase todas as cidades e vilas que visitou, nenhuma autoridade recebeu o grupo paulista com discursos e louvações. Permaneceram anônimos, mas o fato de disporem livremente de um automóvel indicava que os contatos políticos da amiga Olívia Guedes Penteado chegaram a tempo. Tomaram o auto e seguiram para conhecer os principais pontos turísticos da acanhada capital do Ceará do decênio de 1920:

5 de agosto. Fortaleza em frente. Descemos às dez. Automóvel de cá pra lá no ar de limpeza. Mercado, onde compro esteira de carnaúba e goiabada deliciosa. Igrejas sem interesse e o bonito parque da Liberdade. Almoço na Rotisserie com vatapá com leite de coco, maravilha! Tomo nota conscienciosamente das despesas, pagas a dinheiro de não sei quem, barman de bordo? capitão? que dona Olívia me passa. Reparto sempre as despesas comuns, com uma honestidade irritadiça de mais pobre - o que não vai sem graves inconvenientes pra mim. Dona Olívia bem que me censura, se inquieta, eu também me censuro! sei que é bobagem, mas quando chega a hora das contas, não me aguento por debaixo! sou uma besta. Estrada de Maranguape, leite de coco no Balneário, praia de Iracema. Cometo a sem-vergonhice incrível de colher conchinhas da praia de Iracema, me sinto vil como a virgindade. Estrada de ferro do Baturité? - É. - Muito obrigado. - Não por isso. E o embarque difícil, mar grosso. Em Manaus tinha a igreja do Pobre Diabo, em Fortaleza a igreja do Pequeno Grande... (ANDRADE, 2015, p. 198)

A julgar pelas legendas nas fotografias, a manhã, das $10 \mathrm{~h}$ às $11 \mathrm{~h}$, foi gasta em cima do automóvel, dando conta das principais edificações do Centro da cidade: Igreja Coração de Jesus, Mercado Central, Catedral, Seminário da Prainha e a Igreja do Pequeno Grande. O primeiro trajeto circundou a parte da cidade mais típica da "Fortaleza Belle-Époque", expressão designada pelos historiadores para reunir as reformas e discursos de modernização que a capital cearense sofreu entre os anos de 1860 a 1930. As reformas sanitárias e urbanísticas desse período deram uma feição "moderna" à cidade de Fortaleza, relatada por muitos visitantes, entre os quais o avô de Mário de Andrade que esteve na capital cearense em 1882.

Joaquim de Almeida Leite Moraes, assim como o neto, permaneceu menos de $24 \mathrm{~h}$ em Fortaleza. Os seus apontamentos sobre o Ceará dedicam- 
se boa parte do tempo a advogar contra a jangada, de tão traumatizado que ficou com o desembarque, e olhe que Joaquim de Moraes desceu o Araguaia em um bote precário, perdeu seu timoneiro num naufrágio e ele mesmo viu a morte diversas vezes nas cachoeiras e travessões do Tocantins quando se candidatava a afogar-se numa igarité. Mas apesar do "meio de transporte mais bárbaro, selvagem e estúpido", a jangada, o governador interino de Goiás achou a cidade de Fortaleza bem moderna:

Fortaleza é uma bela cidade; edificada sobre uma planície, é bem alinhada; suas ruas em linha reta e bem calçadas; construção em geral elegante e de arquitetura moderna; quarteirões inteiros de um só tipo; a própria casa do pobre tem uma exterioridade decente e agradável. Os seus edifícios públicos, à exceção do palácio, honrariam as províncias mais ricas e mais adiantadas do Império. Fortaleza vestiu com as galas da miséria e ergueu os seus monumentos sobre os alicerces da fome! Calçou as suas ruas e levou o seu luxo ao ponto de calçar caminhos para arrabaldes de casas de palha; fez estradas de ferro, caiou e pintou as suas casas, mas... não substituiu a sua jangada!". (MORAES, 1990)

Durante aquele período, de fato, Fortaleza passou por uma série de reformas urbanas que visavam ordenar e discipliná-la com obras de embelezamento, sanitárias e higienistas. $\mathrm{O}$ traçado em xadrez das ruas do Centro, comentando por Joaquim Moraes, correspondia a uma dessas estratégias de ordenar o espaço público.

Quarenta e cinco anos depois, muitas dessas medidas estavam consolidadas e outras novidades haviam se estabelecido, como o cinema e o bonde, mas Mário de Andrade, diferentemente do avô, não mencionou uma única vez a "modernidade" fortalezense. A lente de sua câmera e o pouco que anotou da visita dirigiram-se, pelo contrário, ao que a cidade guardava de mais antigo. Logo após o rolé pelo Centro, acomodaram-se novamente no Ford e seguiram pela Estrada de Maranguape, no intuito de saborear um caminho mais interiorano.

A estrada de Maranguape era um desses caminhos que se afastava do Centro e punha o viajante em contato com a natureza e as formas de viver mais interioranas. Maranguape é um município próximo à capital cearense e também se destacou por ser uma opção de passeio para as famílias fortalezenses devido ao seu clima mais ameno,serrano. Mário de Andrade e suas companheiras de viagem percorreram de carro um bom 
trecho desta estrada, beirando os trilhos da Estrada de Ferro de Baturité: "Estrada de ferro do Baturité? - É. - Muito obrigado - Não por isso". O diálogo traz a fala coloquial da região, principalmente pela réplica: "Não por isso" - forma bem nordestina de responder a um agradecimento. $\mathrm{Na}$ estrada de Maranguape, Mário de Andrade fotografa carnaúbas e um tipo de casa (Figura 2), cuja legenda se lê: "Pra se se morá com seu bem!".

Figura 2 - "Pra se se morá com seu bem!"

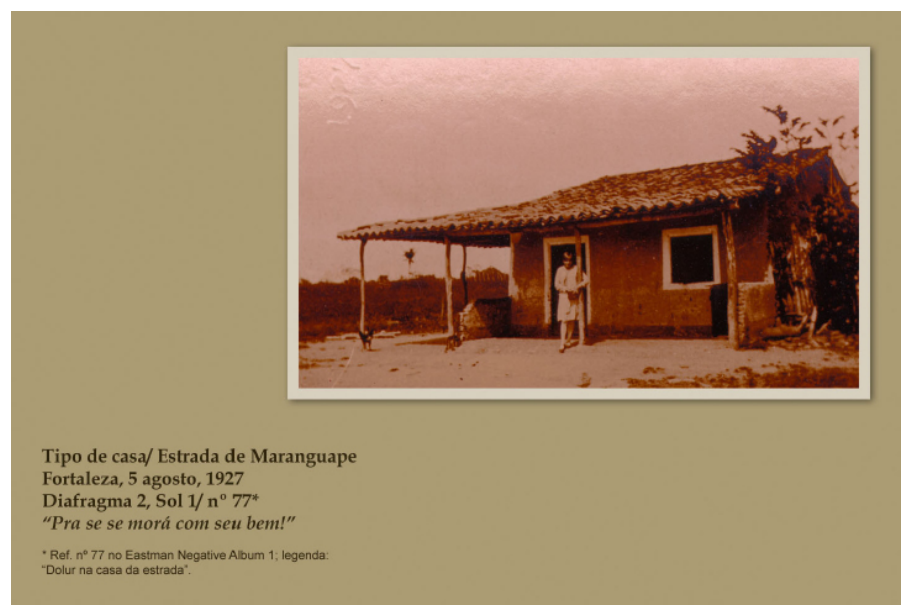

Fonte: Andrade (1927b).

A casa de taipa, a par da legenda jocosa, serve como documento arquitetônico das moradias mais simples da cidade, algo que seria uma preocupação marcante da Missão de Pesquisa Folclórica, idealizada por Mário de Andrade quando chefe do Departamento de Cultura de São Paulo. Da mesma forma, a "codaque" registrou roupas secando ao vento, penduradas numa cerca na beira de uma estradinha, provavelmente nas proximidades do rio Maranguapinho, infladas pela brisa, totemizadas, a ponto de Mário legendar a foto com a rubrica conhecidíssima: "Roupas freudianas"; "fotografia refoulenta/ Refoulement". A fotografia flagra uma etapa do trabalho das lavadeiras, atividade que constituía uma das formas, assim como a renda de bilros e do cuidado dos filhos, de "ajudamento de mulher" (v. nota 2):

A estradinha de areia que se vê na foto "Roupas Freudianas" dimensiona bem em que estado Fortaleza se encontrava em termos de acesso e estrutura. Bastava se afastar um pouco de um núcleo central 
para que a paisagem ganhasse ares de zona campesina. Parece que Mário, Olívia, Margarida e Dolur estavam apenas matando o tempo neste passeio em Fortaleza, aproveitando a carga e descarga do navio para conhecer, mesmo que apressadamente, mais uma cidade do Norte. Logo o automóvel faria meia-volta no sentido de encontrar novamente o mar e o ponto de embarque na Praia de Iracema.

Fortaleza era uma das paradas obrigatórias da viagem de volta a São Paulo, e, já por fim, Mário estava na bancarrota, tanto que, logo mais, em Recife, esperou em vão Ascenso Ferreira na esperança de o amigo pernambucano atender-lhe com algum vintém. $\mathrm{O}$ escritor anotava as despesas pessoais que afiançava à "Rainha do Café", embora essa não demonstrasse preocupação alguma pelas dívidas do amigo professor. Mário comprou itens sem luxo, enfim, era o que a cidade oferecia: uma esteira de palha de carnaúba, uma goiabada e pratos à base de leite de coco e peixe. Se quiséssemos traçar uma história do turismo em Fortaleza, com certeza, O Turista aprendiz traria bons elementos para identificar o perfil dos visitantes, os serviços oferecidos, os equipamentos públicos da cidade, as formas de locomoção, a cultura marítima, a comida típica, o pitoresco, as possibilidades de passeio curto, a arquitetura e o artesanato. Mário se comportou, ao lado das senhoras, como um turista de excursão guiada.

Um dado curioso é que, na segunda metade da década de 1920, a Praia de Iracema começava a ser frequentada pela elite local. E o que era uma praia tipicamente de trabalhadores do mar passava a ser um local de balneário, de prática de esportes, de banho de sol, de mergulho e de tudo o que o mar proporciona como oportunidade de lazer e veraneio. A "Fortaleza Belle-Eppoque", inspirada na França, avançava, com bangalôs, bares e clubes de gosto duvidoso sobre as casas dos jangadeiros, alterando o perfil e o nome da Praia do Peixe, conhecida também como Prainha, Porto das Jangadas, Praia dos Amores:

Nos primeiros anos da década de 1920, as elites que passaram a veranear e frequentar a velha Praia do Peixe acharam por bem, com a ajuda da Imprensa local, reivindicar um novo nome para a localidade, que fosse mais condizente com seu distinto uso. Foi assim que, depois de longas e persuasivas matérias em jornais e revistas locais, a velha praia dos pescadores se transformou em Praia de Iracema, isso em 1925, numa alusão ao romance do conterrâneo José de Alencar. Também as ruas do bairro ganharam nomes de tribos indígenas mencionadas por Alencar em seus romances, 
como a Rua dos Tabajaras, Ruas dos Tremembés, Rua dos Guanacés, entre outras. (ABREU, 2012 p. 41).

Mário pegou esta transição. Seu relato e suas fotos retratam as novas práticas sociais lado a lado com a atividade dos jangadeiros. Segundo Berenice de Abreu, por alguns anos ainda, as famílias dos pescadores viveriam e tirariam seu sustento da Praia do Peixe até que a presença da elite cearense as retirasse do cenário. Mário de Andrade, por exemplo, fotografou "Mag" na praia às $15 \mathrm{~h} 25 \mathrm{~min}$ montada a cavalo, tipo de atração que até hoje os turistas pagam, percorrendo pequenos trechos do litoral de jegue ou a cavalo. Mário fez a seguinte legenda para a foto (Figura 3): "Iracema e o cavalo branco".

O próprio Mário curtiu o dia de sol na praia, caminhando na areia, fotografando, catando conchinhas ou comendo no balneário: “...leite de coco no Balneário, praia de Iracema"13. Os "balneários" eram o apoio aos banhistas, como rememora o senhor Ozarias Ferreira Lima, em relato dado a Fábio de Oliveira Matos (MATOS, 2011, p. 80):

$\mathrm{Na}$ Praia de Iracema surgiu muita coisa bonita, surgiram muitos balneários naquela época, eles eram ótimos para o fim-de-semana. Balneário naquela época [1944] eram os locais onde se guardava a roupa e os objetos pessoais, deixava dentro de uma caixa de madeira numerada e descia para a praia. No fim do dia ia lá tomar banho para tirar o sal do corpo, pois lá tinha várias duchas.

Por outro lado, a máquina fotográfica do poeta deixava resvalar, de soslaio, os usos mais tradicionais da praia. Uma de suas fotos mostra uma jangada sendo retirada do mar. A embarcação, arqueada por uma grande forquilha para que pudesse levemente repousar e deslizar por sobre roletes de carnaúba, regressava de uma pesca farta, haja vista os pescadores olharem para os samburás antes mesmo de finalizar o trajeto para fora do campo da maré.

13 "O correio chegou e na minha correspondência estava um jornal, quem me mandou não sei. Era um diário de uma linda capital do Norte. Já estive nela, passei lá um dia sublime, até colhi conchinhas na praia. Pois fui lendo os títulos do jornal e imaginem de quem era o escrito sobre José Pompeu da Silva Brasil! era meu! meu-teu-seu-nossovosso-deles!" (ANDRADE, 2013, p. 74) 
Figura 3 - Iracema e o cavalo branco

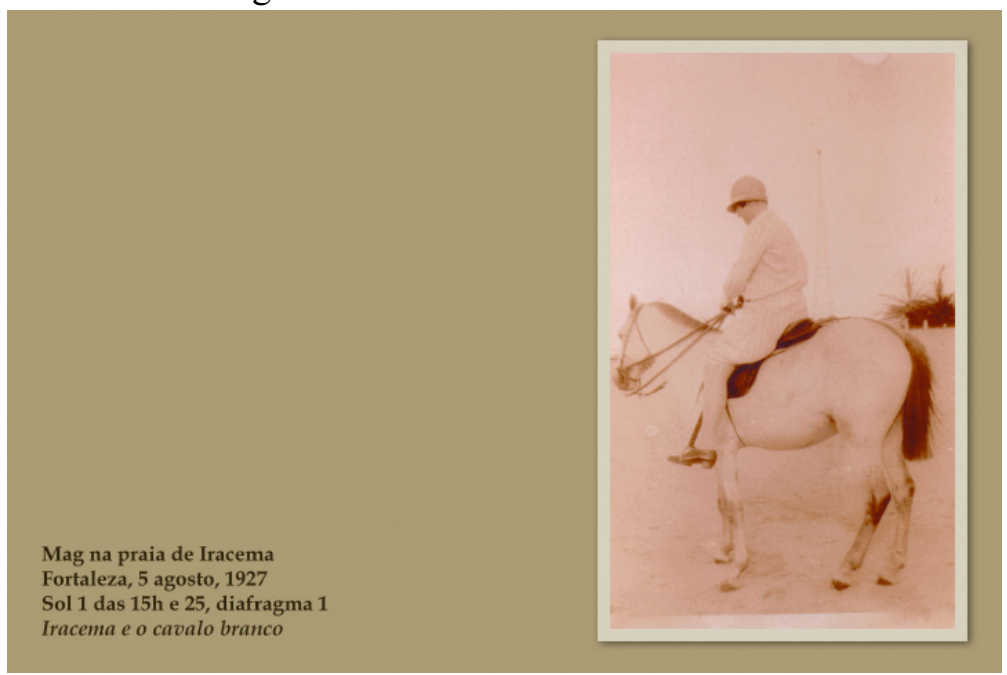

Fonte: Andrade (1927c).

O olhar do Mário fotógrafo vai revelando um Ceará urbano, litorâneo e outro mais continental num pequeno raio de distância, dando a medida da modernização de Fortaleza nas suas zonas territoriais limítrofes, o que de certo modo mesura as diferenças regionais do país e do movimento modernista que, a esta altura, já havia chegado aos cearenses por outras vias. O que o fotógrafo e autor procurava na viagem não eram índices comumente atribuídos à modernização do século XX, tais como luz elétrica, avenidas largas, bondes, automóveis, cinemas etc., mas sim "índices de nacionalidade" 14 . Em carta a Câmara Cascudo datada de 26 de setembro de 1924, Mário dá uma ideia do que seriam estes "índices nacionais", ao pedir ao amigo potiguar imagens daquilo que considera o Brasil:

Há por aí obras de arte coloniais? Imagens de madeira, igrejas interessantes? Conhecem-se os seus autores? Há fotografias? Acredite: tudo isso me interessa mais que a vida. Não tenha medo de me mandar um retrato de tapera que seja. Ou de rio, ou de árvores comuns. São as delícias de minha vida essas fotografias de pedaços mesmo corriqueiros do Brasil.

14 "Os pratos nativos são índices de nacionalidade/ Mas Grande Hotel de Belo Horizonte servem à francesa" poema "Noturno para Belo Horizonte"(ANDRADE, 1976, p. 57) 
Não por sentimentalismo. Mas sei surpreender o segredo das coisas comezinhas da minha terra. E minha terra é ainda o Brasil. Não sou bairrista. (CASCUDO; ANDRADE, 2010, p.39.)

O trecho da carta contém o espírito da viagem que faria anos depois, explicando que por trás do prazer e da alegria do viajante aprendiz havia um compromisso engajado do artista a documentar "pedaços corriqueiros" do país, justificando a escolha de fotografar em Fortaleza a jangada, a carnaúba, a casa de taipa, o movimento desordenado do mercado central, a praia, as roupas no varal, a cerca. A Fortaleza de Mário de Andrade não era definitivamente a "Fortaleza Belle-Époque" dos casarões do Centro, a influência francesa, os boulevards, o Passeio Público, as ruas planejadas por Silva Paulet, mas sim a Fortaleza corriqueira, "os segredos das coisas comezinhas da minha terra".

Mais do que o polígrafo, é o fotógrafo que revela literalmente o caráter nacional escondido nos recônditos da cidade, "clareiras do Brasil, praças agrestes", para ainda citarmos o "Noturno para Belo Horizonte" do livro Clã do Jabuti que, aliado ao Ensaio sobre a música brasileira, desenvolve a doutrina modernista andradina da década de 1920, duplamente de base universal e nacionalista. No mesmo compasso, as fotografias e a própria viagem ao Norte do país corroboram com o princípio investigativo, de pesquisa séria e obstinada, que Mário dizia necessário à empreitada modernista. Este espírito de pesquisador acurado somava-se ao gosto genuíno do autor pelo Brasil e pelos brasileiros.

Terminado o rolé pela cidade, embarcam novamente no navio, desta vez no rumo de São Paulo: embarque difícil, mar grosso, o que lembra a descrição inicial dos verdes mares bravios transformados em canavial quando em maio, quatro meses antes, pararam no litoral cearense sem desembarcar. Estava finda a viagem ao Ceará.

\section{Referências}

ABREU, Berenice de. Jangadeiros: uma corajosa jornada em busca de direitos no Estado Novo. Rio de Janeiro: Civilização Brasileira, 2012.

ALENCAR, José de. Cartas sobre a Confederação dos Tamoios. Diário do Rio de Janeiro. Rio de Janeiro, 1856.

ANDRADE, Mário de. Aspectos da literatura brasileira. 6. ed. Belo Horizonte: Editora Itatiaia, 2002.

ANDRADE, Mário de. Iracema e o cavalo branco. 5 ago. 1927c. 1 fotografia. 
ANDRADE, Mário de. Macunaíma: o herói sem nenhum caráter. Rio de Janeiro: Livraria Garnier, 2001.

ANDRADE, Mário de. No pontão de Fortaleza. 5 ago. 1927a. 1 fotografia.

ANDRADE, Mário de. O Turista aprendiz. Edição de Telê Ancona Lopez; Tatiana Longo Figueiredo e Leandro Raniero Fernandes. Brasília: IPHAN, 2015.

ANDRADE, Mário de. Os filhos da Candinha. Rio de Janeiro: Nova Fronteira, 2013.

ANDRADE, Mário de. Pauliceia Desvairada. São Paulo: Casa Mayença, 2002.

ANDRADE, Mário de. Poesias completas - Mário de Andrade. São Paulo: Círculo do Livro, 1976.

ANDRADE, Mário de. Prá se se mora com seu bem! 5 ago. 1927b. 1 fotografia.

ARANHA, Graça. O meu próprio romance. Rio de Janeiro: Companhia Editora Nacional, 1931.

CANDIDO, Antonio. Literatura e sociedade. 11. ed. Rio de Janeiro: Ouro Sobre Azul, 2010.

CASCUDO, Câmara; ANDRADE, Mário de. Organização de Marcos Antônio de Moraes. Cartas 1924-1944. São Paulo: Global, 2010.

MARQUES, Rodrigo de Albuquerque. A nação vai à província: do Romantismo ao Modernismo no Ceará. Fortaleza: Imprensa Universitária, 2018a. p. 164-184.

MARQUES, Rodrigo de Albuquerque. Literatura cearense: outra história. Fortaleza: Dummar, $2018 b$.

MATOS, Fábio de Oliveira. A cidade e o mar: considerações sobre a memória das relações entre Fortaleza e o ambiente litorâneo. Revista Geografia, Ensino \& Pesquisa, Santa Maria, v. 15, n. 1, p. 71-84. jan/abr. 2011. DOI: https://doi.org/10.5902/223649947378.

MORAES, Joaquim de Almeida. Apontamentos de viagem. São Paulo: Companhia das Letras, 1990. E-book. 
GRAVAÇÃO rara reproduz a voz de Mário de Andrade LADO 1. [S. l: $s$. n.], 2015. 1 vídeo (5 min). Publicado pelo canal Daniel Santos. Disponível em:https://www.youtube.com/watch? $v=$ ThlmeniUH9c\&t=170s. Acesso em: 13 jul. 2021.

SOUZA, Gilda de Melo e. O tupi e o alaúde: uma interpretação de Macunaíma. São Paulo: Duas Cidades, 1979. 